Кушнірук Ю. С. ${ }^{[1 ; 0 R C I D ~ I D: ~ 0000-0003-4733-3032], ~}$ к.геогр.н., доцент,

Семенов С. С. ${ }^{[1]}$, здобувач вищої освіти другого (магістерського) рівня

${ }^{1}$ Національний університет водного господарства та природокористування, м. Рівне

\title{
СПОРТИВНИЙ АВТОТУРИЗМ - ЕКОНОМІЧНІ ЧИННИКИ РОЗВИТКУ
}

Статтю присвячено дослідженню різновидів спортивного автотуризму. Наводиться історія розвитку цих напрямків туризму. Розглядаються причини популярності спортивного автотуризму. Аналізуються економічні аспекти розвитку спортивного автотуризму. Пропонуються напрями розвитку спортивного автотуризму в Україні.

Ключові слова: спортивний автотуризм; туристичний продукт; туристична індустрія; економічні чинники; ринок туристичних послуг; туристичні ресурси; міжнародний туризм.

Постановка наукової проблеми та її значення. Спортивний автотуризм - це поєднання автотуризму та автоспорту. Автоспорт зародився на початку XX ст. практично з появою перших серійних спортивних автомашин. Класичний автотуризм розвинувся після Другої світової війни в Північній Америці як подорожі (в тому числі сімейні) під час відпустки по автомагістралям США між Атлантичним та Тихоокеанським узбережжями країни або між кордонами 3 Мексикою та Канадою. На сьогоднішній день поєднання автоспорту та автотуризму дало розвиток новим різновидам екстремального туризму, які мають потужний маркетинг та займають все більший сектор на ринку туристичних послуг. Дослідження розвитку різновидів спортивного автотуризму та економічних чинників зростання цього виду туризму має значення для розробки стратегії розвитку туристичної галузі загалом.

Актуальність аналізованої проблеми визначається стрімким зростанням популярності спортивного автотуризму в останні десятиріччя та обумовлена необхідністю підвищення економічної ефективності функціонування автомобільного туризму.

Мета дослідження полягає у дослідженні розвитку окремих різновидів спортивного автотуризму та економічних чинників цього виду туризму.

Об'єктом дослідження $є$ спортивний автотуризм.

Предметом дослідження $\epsilon$ економічні аспекти розвитку 
окремих різновидів спортивного автотуризму.

Методологічною основою дослідження $\epsilon$ теоретичні положення туризмології, рекреалогії, туристичного країнознавства, міжнародного туризму, економіки туризму тощо.

\section{Виклад основного матеріалу}

Окремі аспекти розвитку автотуризму розглядали Біржаков М. Б. Нікіфорова В.І., К Котов Г.Г., Чудновський О. Д., Цибух В.І., Худо В. В. Мальська М. П., Гуляєв В.Г., Александрова А. Ю., Вершицький А. В. тощо. Переважно їх праці присвячено «туристським перевезенням і їх місцю у складі туристського продукту, використовуванню транспортних засобів в цілях туризму, у тому числі як засобів розміщення» [1]. Окремі автори розглядали стан організації відпочинку автотуристів, територіальні і екологічні умови формування мережі автостоянок, кемпінгів і мотелів.

Автоспорт - це технічний вид спорту, що містить у собі всі види змагань на різних типах автотранспортних засобів: гоночних, вантажних, серійних, спортивних і других автомобілях. Одні змагання можуть відрізнятися від інших способом проведення, дистанцією, класом автомобілів. Клас автотранспортного засобу визначається за об'ємом циліндрів у двигуні, вагою авто й елементами конструкції. Всі критерії й ознаки, за якими класифікуються автомобілі, що використовуються для участі в автоспорті, зазначені в Міжнародному спортивному кодексі.

Уперше автоспорт заявив про себе в 1893 році, коли видавець паризької газети «Le Petit Journal» П'єр Жифар, заявив, що найближчим часом буде проведена перша автомобільна гонка. «Учасникам необхідно було проїхати дистанцію від Парижа до Руана (відстань 126 км), пройти її треба було менш чим за 8 годин. Там були автомобілі й на парі, і на бензині, і на гасі, і на електриці» [1].

Сьогодні, автогонки являють собою особливо потужний маркетинговий інструмент. Також, автоспорт $€$ багатомільярдним бізнесом, у якому беруть участь не тільки автоспортсмени, але й міжнаціональні корпорації.

Автотуризм почав зароджуватись на початку XX ст. Перші подорожі на особистому автотранспорті стали відбуватися в міру розвитку автомобільної промисловості на початку XX століття, але на відміну від автоспорту, найбільшу популярність цей вид туризму придбав у післявоєнний час. У цей період автомобільні компанії стали активно випускати нові моделі особистого транспорту, а держави - будувати автостради. 
Найбільше динамічно автотуризм розвивався в США, де в середині XX століття у зв'язку зі стрімким зростанням добробуту громадян i налагодженим автомобілебудуванням подорожі на особистому транспорті придбали масовий характер.

Одним 3 найпоширеніших визначень автотуризму $є$ наступне визначення: «автомобільний туризм - подорожі людей у країни або місцевості, відмінні від їхнього постійного місця проживання, у яких основним засобом пересування виступає приватний або орендований автомобіль» [1]. Серед видів активного туризму цей найбільш комфортний, сполучається з різними перевагами туристів під час подорожі й відпочинку [3].

В останні роки і в Україні помітно зріс інтерес до автомобільного туризму. Це можна пояснити рядом причин. Значно виріс парк особистого автотранспорту за рахунок імпорту закордонних автомобілів після розпаду СРСР. Підвищилася надійність автомобільної техніки. Широкого поширення набули повноприводні автомобілі. Покращилися можливості 3 ремонту автомобільної техніки закордонних марок. В Україні автотуризм в основному $\epsilon$ самостійним видом туризму. Різні люди з різних причин вибирають цей вид туризму. Автотуризм дає найбільшу волю вибору: свого маршруту (дороги, місця зупинок і стоянок), часу подорожі, імпровізації програми під час подорожі. «Людина, що подорожує на автомобілі, не обмежується в просторі. При цьому виключається проблема з тим, на чому добратися до потрібного місця. Постійна наявність автотранспорту робить туриста дуже мобільним і дозволяє побачити максимально велику кількість туристських об'єктів Автотурист може в будь-який момент змінити маршрут, закінчити або продовжити подорож» [2].

В автомобільному туризмі ширше можливості планування поїздки відповідно до свого бюджету. «Часто автомобільний туризм дозволяє знизити транспортні витрати й витрати на проживання. Особливо вигідний автотуризм при подорожі всією родиною. Часто це єдина можливість здійснити поїздку разом з родиною» [5].

Поява GPS також вплинуло на розвиток автотуризму. Навігатори дозволяють планувати маршрути 3 урахуванням дорожньої розмітки й дорожніх пробок на шляху, зберігати історію минулих маршрутів, вести приблизний розрахунок палива тощо.

Серед економічних чинників причиною розвитку, наприклад караванінгу, $€$ те, що подорож на автомобілі родини з 3-4 чоловік дешевше на $30-40 \%$ у порівнянні з подорожжю на авіатранспорті, по залізниці або в рамках готового туру.

Одними з популярних видів автомобільного туризму $\epsilon$ 
караванінг і сафарі. Багато туристичних компаній пропонують як особлива послуга подорож на машині по Африці.

Для економіки туристичної галузі ці види автотуризму важливі: караванери вносять вклад в економіку не менше, ніж класичні туристи. «Вони платять за бензин, газ, за ті ж мотелі або автокемпінги, харчування, сувеніри, відвідування музеїв і національних парків. Всі ці витрати входять в економіку туристичної галузі, причому автотуристи здатні доїхати туди, куди звичайні туристи не доберуться, тому вони важливі для малих міст і віддалених територій. Крім того, в місцях організованих стоянок розміщують кафе, сувенірні крамниці, мініринки» [5].

Для звичайного автотуризму на орендованому авто є різниця, в якій країні планувати подорож (таблиця), це залежить від ціни на паливо, вартості оренди автомашини тощо.

Таблиця

Вартість автотуризму в різних країнах Європи

\begin{tabular}{|l|c|c|c|}
\hline \multicolumn{1}{|c|}{ Країна } & $\begin{array}{c}\text { Ціна палива } \\
\text { (євро) }\end{array}$ & $\begin{array}{c}\text { Ціна оренди } \\
\text { авто (євро, } \\
\text { тиждень) }\end{array}$ & $\begin{array}{c}\text { Ціна 800-км } \\
\text { подорожі (євро) }\end{array}$ \\
\hline Іспанія & 1,4 & 78 & 171 \\
\hline Португалія & 1,6 & 83 & 190 \\
\hline Великобританія & 1,6 & 126 & 234 \\
\hline Німеччина & 1,6 & 131 & 240 \\
\hline Франція & 1,5 & 140 & 240 \\
\hline Греція & 1,6 & 168 & 277 \\
\hline Швейцарія & 1,4 & 189 & 285 \\
\hline Італія & 1,8 & 166 & 286 \\
\hline Нідерланди & 1,8 & 178 & 441 \\
\hline Норвегія & 1,9 & 315 & 297 \\
\hline
\end{tabular}

Зараз подорож на автомобілях по бездоріжжю прийнято називати джипінгом. «Джипінг - це екстремальна поїздка на джипах та інших автомобілях високої прохідності, що проходить, як правило, по бездоріжжю. Нерідко цікаві туристичні об'єкти перебувають далеко від наїжджених зручних доріг або шосе, і туристам доводиться їхати по лісових дорогах, степу або пустелі, переборювати природні перешкоди, у тому числі й водні броди. Для подолання перешкод автомобілі повинні мати підвищену прохідність» [4]. Цим цілям відповідають джипи або позашляховики.

Але більше екстремальні види автотуризму, що належать до спортивного автотуризму, це авторалі, драг-рейсінг, дрифт, авто 
слалом, автобол.

В авторалі учасники змагаються у водійській майстерності на довгих й коротких дистанціях.

Довга дистанція ралі - найбільш доступна, тому взяти участь можуть автомобілі будь-якої комплектації. Під час проходження маршруту учасникам пропонується вирішувати різні завдання, зокрема на орієнтування, взяття контрольних точок, подолання спеціальних ділянок тощо.

Короткі дистанції більше розраховані на прохідні авто.

«Тріал» туризм - це дистанція, на якій треба переборювати локальні перешкоди - косогір, ями, колії та ін. Це можна зробити на стандартному позашляховику.

«Тріал Екстрим» розрахований уже на позашляховики підвищеної прохідності. Також треба буде проїхати дистанцію в 2 км із перешкодами.

Інший вид спортивного автотуризму: драг-рейсінг «... гоночне змагання, що є спринтерським заїздом на дистанцію в 402 метра (1/4 милі). Рідше проводяться заїзди на 1/2 милі (близько 804 м), 1/8 милі (201 м) або на мірну милю (1609 м). По суті драг-рейсінг, є перегонами на прискорення, що проводиться на прямій трасі» [4].

Розвитку драг-рейсінгу в США допомогло становлення промисловості й фінансової сфери після 2 світової війни. Вже в другій половині 40-x і початку 50-х через конкуренцію автовиробники оновлювали модельний ряд раз у рік-два. А все те, що було створено до війни, при бурхливому розвитку ринку коштувало дуже мало, скуповувалося молоддю й перетворювалося в автомобілі для різних видів автозмагань, в тому числі драг-рейсінгу. «Обрізані стійки даху, задні колеса збільшеного діаметру, форсований мотор, посилений каркас» [1].

у Європі драг-рейсінг розвивався не так інтенсивно позначились економічні наслідки другої світової війни. У Європі ці перегони по популярності не зрівнялися з Америкою, тут більш популярне ралі. А в США існує 24-етапний національний чемпіонат, близько 150 трас, понад 100 тисяч членів тільки в National Hot Rod Association і більше 5 тисяч щорічних тематичних моторшоу.

Інший різновид спортивного автотуризму - дрифт. «Автомобіль дрифтує, коли кут відведення задніх коліс перевищує такий у передніх, причому найчастіше настільки, що передні колеса спрямовані у протилежний повороту бік» [5].

Дрифт зародився в Японії. У 70-і роки екстремальні автотуристи почали освоювати новий для себе спосіб вийти 3 повороту 3 мінімальними втратами у швидкості й крутному моменті. Спочатку 
заїзди були одиночними, але через деякий час дрифт-змагання прийшли до формату «дуелі», коли в заїзді одночасно беруть участь два гонщики, що змагаються між собою й одержують бали за результатами проходу траси. Судді при цьому оцінюють чотири основних параметри: траєкторія, кут, швидкість і стиль.

3 економічної точки зору, як і для драг-рейсінгу, так і для дрифту потрібно вкласти дуже багато коштів, щоб перетворити серійний автомобіль на спортивний. «Для успішного дрифту не підходить будь-який середньостатистичне авто. Мало мати просто задній привід - треба створити на задніх колесах запас потужності, що дозволить водієві викликати їхню пробуксовку при проходженні повороту» [1]. Для створення дрифт-кара потрібен задньоприводний автомобіль із потужним двигуном (як і для драг-рейсінгу), як правило, максимально полегшений і підготовлений до заїздів. Однією з основних складових дрифт-кара $є$ задній диференціал. Саме він забезпечує пробуксовку одночасно двох задніх коліс, без якої не можна домогтися ні тривалого керованого замету, ні успіхів у змаганнях. Двигун автомобіля для дрифту повинен витримувати високі навантаження, при цьому працюючи максимально довго, тому що він не міняється після кожних змагань, як це може відбуватися в професійних автогонках 3 величезними бюджетами. Також модифікуються коробки передач, підвіска, рульове керування тощо. У цілому всі перераховані вище модифікації дозволяють створити дрифт-кар, але й й коштує це немало, тому представники цього виду автотуризму вкладають чи не найбільше коштів у галузі туризму в перерахунку на одного туриста [6].

Наступний вид спортивного автотуризму - time-attack. Ця дисципліна в автоспорті практично нічим не відрізняється від стандартних кільцевих гонок, але $є$ одна істотна відмінність: гонка проходить без масового старту автомобілів, і переможець визначається за кращим часом, за яке був пройдений коло, тому це мінімальний ризик для автогонщика в порівнянні 3 іншими дисциплінами в автоспорті. Під час перегонів по пересіченій місцевості або в масовому заїзді на кільцевій трасі підвищується ймовірність аварії, а це може призвести до травм водія й значних ушкоджень автомобіля. Усього цього позбавлений гонщик у дисципліні time-attack, тому що на трасі він перебуває один і єдиний його супротивник - це час, що повинен бути кращим.

Ще один досить популярний і в Україні вид спортивного автотуризму - автокрос. Це перегони на спеціальних автомобілях по кільцевій трасі без спеціального покриття. Такі змагання проводяться практично у всіх регіонах цілий рік. Для участі в 
перегонах необхідний модифікований автомобіль, що буде відповідати всім вимогам техніки безпеки. Популярний цей вид спортивних гонок з ряду причин, це: огляд всієї траси для глядачів, масовість гонки, контактна боротьба на трасі, на трасах для автокросу часто зустрічаються ями, трампліни, підйоми що додає атрактивності цього виду змагань.

В XXI ст. підходи до функціонування автомобільного туризму, які існували раніше, застаріли і не відповідають ринковим вимогам. «Вимагають дослідження питання нового підходу до формування організаційних структур як форми, яка забезпечує ефективний розвиток автомобільного туризму, підприємств, що входять до його складу, принципів їх функціонування. Ці питання вимагають нових наукових i методичних розробок для оцінки, підвищення його економічної ефективності i розвитку технологій послуг для автотуристів» [5].

Можливе збільшення конкурентоспроможності автомобільного туризму в Україні шляхом підвищення ефективності функціонування підприємств, що входять до його складу. «Конкуренція на внутрішньому i міжнародному туристських ринках визначає необхідність розробки спеціальних методів управління підприємствами, пошуку шляхів формування конкурентноздатної пропозиції, ефективної взаємодії між підприємствами автомобільного туризму, а також ефективної системи просування послуг на туристських ринках» [5].

\section{Висновки}

3 економічної точки зору автомобільний туризм - це система підприємств, які забезпечують туристів, що подорожують на власному або орендованому автомобільному транспорті та беруть участь у різних видах спортивного та екстремального автотуризму.

Україна має великий практичний досвід організації автотуризму. Особливо розвинений був туризм на приватному автомобільному транспорті. Для автотуристів розроблялися маршрути різної категорії складності, вони забезпечувалися картами-схемами. Незважаючи на певні труднощі, автотуризм активно розвивався. Україна має достатній фізико-географічний, кліматичний i історико-культурний потенціал для розвитку автотуризму, причому не тільки для українських громадян, але й для іноземного туриста [2].

В останні десятиріччя в Україні намітилося пожвавлення в сфері економіки автомобільного туризму, досягнуті певні рубежі розвитку інфраструктури. Значна увага приділяється розвитку й удосконаленню автомобільних доріг; більша автопрокатна мережа; $\epsilon$ 
розгалужена мережа автозаправних станцій й пунктів СТО. Подальший розвиток одержала мережа розміщення автотуристів від невеликих готелів, кемпінгів, мотелів до наметових містечок і платних стоянок.

Транзитні автотуристи мають можливість одержати харчування в численних пришляхових ресторанах, кафе, буфетах, що працюють цілодобово, а це розвиток супутньої галузі туризму - готельноресторанної справи.

Поряд з позитивними тенденціями в сфері автотуризму України $€$ ще невирішені проблеми. Дана сфера розвивається стихійно, на основі приватного підприємництва й під час відсутності державного регулювання, тому не відповідає рівню міжнародних стандартів. Заклади розміщення та харчування, торгівля розвиваються на основі приватної ініціативи, найчастіше, без осмисленого державного регулювання. Це найчастіше призводить до того, що нові підприємства заважають роботі існуючих, призводять до їхнього занепаду. Кадри, у таких закладах, підбираються на основі сімейних зв'язків і часто не відповідають вимогам необхідної кваліфікації.

Таким чином, можна прийти до висновку, що автотуризм, для свого потенційного розвитку вимагає загальнодержавної програми, що враховувала б усі складові даної сфери туризму.

Подальшого вдосконалювання вимагають автомобільні траси; пункти розміщення автотуристів; спрощення системи прокату автомобіля; удосконалення інформаційної бази для автотуристів можливість придбати конкретні схеми-маршрути, карти автомобільних доріг регіонів подорожі та ін.

Рекреаційно-туристичне господарство України має перспективи розвитку, в тому числі завдяки поширенню спортивного автотуризму, для якого на території багатьох регіонів $€$ потужний туристичний потенціал та різноманітні туристично-рекреаційні ресурси. Економічний потенціал спортивного автотуризму може стати одним 3 провідних в туристичній галузі України завдяки своїй специфіці залучення заможних автотуристів, як того вимагає утримання та використання засобів цього виду туризму.

1. Гиффорд К. Современный автоспорт. Энциклопедия. Москва: Росмэн-Пресс, 2007. 144 с. 2. Казанжи О. Ф. Розвиток спортивного туризму: історія і сучасність. Туристичний та готельно-ресторанний бізнес: світовий досвід та перспективи розвитку для України : матеріали Всеукраїнської науково-практичної конференції. Одеса: ОНЕУ, 2019. С. 227-229. 3. Кушнірук Ю. С. Рекреація та курортологія : навч. посіб. Рівне: НУВГП, 2012. 146 с. 4. Мелентьев Ю.А. Автомотоспорт. Малая энциклопедия. Москва: ЛитРес, 2019. 98 с. 5. Морозов М. А. Экономика туризма. Москва: Федеральное агентство по туризму, 2014. 320 с. 6. МуликК.В., 
Пруднікова М. С., Гриньова Т.І. Основи спортивного туризму в рекреаційній діяльності. Збірник наукових праць. Харків : ХДАФК, 2016. 358 с.

\section{REFERENCES:}

1. Gifford K. Sovremennyiy avtosport. Entsiklopediya. Moskva : Rosmen-Press, 2007. 144 s. 2. Kazanzhy O. F. Rozvytok sportyvnoho turyzmu: istoriia i suchasnist. Turystychnyi ta hotelno-restorannyi biznes: svitovyi dosvid ta perspektyvy rozvytku dlia Ukrainy : materialy Vseukrainskoi naukovo-praktychnoi konferentsii. Odesa : ONEU, 2019. S. 227-229. 3. Kushniruk Yu. S. Rekreatsiia ta kurortolohiia : navch. posib. Rivne: NUVHP, 2012. 146 s. 4. Melentev Yu. A. Avtomotosport. Malaya entsiklopediya. Moskva : LitRes, 2019. 98 s. 5. Morozov M. A. Ekonomika turizma. Moskva : Federalnoe agentstvo po turizmu, 2014. 320 s. 6. Mulyk K. V., Prudnikova M. S., Hrynova T. I. Osnovy sportyvnoho turyzmu $\mathrm{v}$ rekreatsiinii diialnosti. Zbirnyk naukovykh prats. Kharkiv: KhDAFK, 2016. $358 \mathrm{~s}$.

Kushniruk Y. S. [1; ORCID ID: 0000-0003-4733-3032], Candidate of Geographical Sciences (Ph.D.), Associate Professor, Semenov S. S. ${ }^{[1]}$ Graduate Student

${ }^{1}$ National University of Water and Environmental Engineering, Rivne

\section{SPORTS AUTO TOURISM - ECONOMIC FACTORS OF DEVELOPMENT}

The article is devoted to the study of varieties of sports tourism. The relevance of the study is determined by the fact that in recent decades, sports motoring is a particularly powerful marketing tool and is a multibillion-dollar business, which involves not only motorists but also international corporations. The purpose of the study is to study the history of development of certain types of sports tourism and economic factors of this type of tourism. The object of study is sports tourism. The subject of research is the economic aspects of the development of certain types of sports tourism. The methodological basis of the study is the theoretical provisions of tourism, recreation, tourism, international tourism, tourism economics and more. The reasons for the popularity of sports tourism are considered. The economic aspects of the development of sports tourism are analyzed. Ukraine has extensive practical experience in organizing motor tourism and has sufficient physical-geographical, climatic and historicalcultural potential for the development of motor tourism, not only for Ukrainian citizens but also for foreign tourists. The directions of development of sports motor tourism in Ukraine are offered. Recreational and tourist economy of Ukraine has prospects for development, including due to the spread of sports tourism, for which in many regions there is a strong tourist potential and a variety of tourist and recreational resources. 
Along with the positive trends in the field of motor tourism in Ukraine, there are still unresolved issues. This area is developing spontaneously, on the basis of private enterprise and in the absence of state regulation, so it does not meet the level of international standards. Motorways require further improvement; motorhome accommodation points; simplification of the car rental system; Improving the information base for motorists - the opportunity to purchase specific schemes-routes, road maps of travel regions, etc. In solving these problems, the economic potential of sports tourism can become one of the leading in the tourism industry of Ukraine.

Keywords: sports auto tourism; tourist product; tourist industry; economic factors; market of tourist services; tourist resources; international tourism.

Кушнирук Ю. С. ${ }^{[1 ;}$ ORCID ID: 0000-0003-4733-3032], к.геогр.н., доцент,

Семёнов С. С. ${ }^{[1]}$, соискатель высшего образования второго (магистерского) уровня

${ }^{1}$ Национальный университет водного хозяйства и природопользования, г. Ровно

\section{СПОРТИВНЫЙ АВТОТУРИЗМ - ЭКОНОМИЧЕСКИЕ ФАКТОРЫ РАЗВИТИЯ}

Статья посвящена исследованию разновидностей спортивного автотуризма. Приводится история развития этих направлений туризма. Рассматриваются причины популярности спортивного автотуризма. Анализируются экономические аспекты развития спортивного автотуризма, предлагаются направления его развития в Украине.

Ключевые слова: спортивный автотуризм; туристический продукт; туристическая индустрия; экономические факторы; рынок туристических услуг; туристические ресурсы; международный туризм. 